\title{
State and identity: The controversies of identity change in Croatian society in the 1990s
}

\author{
Albert Bing \\ Review article \\ UDK 316.644:32(497.5)"199" \\ 316.75:32(497.5)"199"
}

\begin{abstract}
Statehood and nation-building, wars and social transition were some of the basic (internal) elements which determined the complexity of identity changes in Croatian society at the end of the 1980s and the beginning of the 1990s. The shift to plural society at a time of increasing national tensions in Croatia and Yugoslavia activated wide-scale identity reconstruction, ranging from a tendency toward modernization to a revival of violent and exclusive ethnonational paradigms. Extremely complex historical circumstances, combined with the extraordinary tempo of change - "the acceleration of history" - resulted in some controversial aspects of identity reconstruction: the concept of nationstate building in relation to identity, the problem of redefining the identity of the warring nations in terms of national homogenization and the implementation of the so-called humane resettlement of nations as solutions to interethnic conflict.
\end{abstract}

Keywords: Croatia, Yugoslavia, national identity, national homogenisation, humane resettlement, Franjo Tuđman, Dobrica Ćosić 


\section{Introduction}

Contemplating trends in European history during the final decade of the $20^{\text {th }}$ century (1993), Alain Minc recalled that the vision of a "privileged people" of the nation-state in the past, as in the present, easily devolved to extremes: “... when viewed from the standpoint of jus sanguinis, the European map is inextricable, it signifies chain of conflicts"; the 1990s led to the violation of "the taboo which guaranteed peace on the continent for almost a half-century: the one concerning the integrity and inviolability of borders"(Minc 2008: 29, 38). Minc's observations were among the many analyses that dealt with the collapse of the multiethnic Yugoslav state and the creation of nation-states on its ruins. "Local spasms in the Balkans" prompted an entire avalanche of questions in which there was no lack of controversy. The emergence of national homogenization prompted the exclusively understood right to national selfdetermination and, ultimately, the establishment of independent nation states. These processes activated a "preserved" identity, outdated notions of selfidentification caught in various stages of the development of national ideologies and national integration processes of the $19^{\text {th }}$ and $20^{\text {th }}$ centuries.

In this complex historical context, this paper will parse and analyse the phenomenon that marked the identity controversies in Croatia and Yugoslavia from the standpoint of affirmation of the nation-state. What consequences did statehood aspirations have on the changes in identity of the warring nations (which become national minorities after the collapse of the Yugoslav state and the establishment of new nation-states)? What led to the attempt to implement the idea of exchanging populations between the warring factions? Were these phenomena the result of inter-ethnic conflict which became a genocidal war or the $a$ priori ideological paradigm of the leading Croatian and Serbian politicians?

In methodological terms, this work is a historical and political-science study of very recent history. Together with the incorporation of the relevant scholarly and political assessments of events and phenomena that emerged at the time or with a short time delay, this work is based on an analysis and interpretation of materials collected during a specified period. 


\section{Identity, transition and the dissolution of Yugoslavia}

In his analysis of the dialectics of national identity in Yugoslavia, John Allcock pointed out that "identity can neither be defined nor function at either the personal or collective level without reference to others - those who are not like us and from whom we need to distinguish ourselves. Who 'we' are is in variably defined in relation to who 'we' are not" (Allcock 2000: 328). In this respect, a vital role was "played by symbols of national identity as 'border guards' demarcating groups from one another" (Allcock 2000: 328). As observed by sociologist Slaven Letica, who tried to define the ethnocentric background of the Croat-Serb relationship (in terms of the most important Yugoslav national rivalry), national demarcation could be explained by the concept known as the narcissism of small differences. Namely, "some of the ethnic and cultural differences between Serbs and Croats (e.g. differences in languages, customs, etc.) are so small that their conservation and emphasis in certain historical and political circumstances become a matter of preservation of ethno-national independence. And that is the source of intolerance and aggression in interethnic relationship" (Čović 1991: 11-12).

Many conflicts that had developed in Yugoslavia long before 1991 exhibited a tendency to define the constitutional character of each national group - in order to gain their own national state - as "belonging primarily to an ethnic group, to the ethnos, and not the demos" (Dimitrijević 2012: 20). In political practice, this tendency meant that despite the declarative commitment to human rights and democratic values-proclaimed by all participants in the break-up of Yugoslavia - diversity became not just an undesirable but moreover a troublesome factor (Bing 2008: 215). The transitional process of political liberalization in Croatia in the 1990s led to a re-evaluation of many cultural and other forms of identities: economic, religious, generationally-dictated, rural and urban, regional, etc. However, the most decisive factor was the emergence of the nation as the prevailing form of identification, and, consequently, nationalism as the dominant value system "which lay at the core of identity politics in 1990s Croatia" (Prica 2012: 133). The changes associated with the violent collapse of Yugoslavia had a substantial, probably crucial, impact on the formation of contemporary Croatian or post-Yugoslav social and collective identities.

Very different and controversial transformations of identities (these processes have both a temporal and spatial character) can be identified in this historical context. Most analyses of Yugoslavia's dissolution claimed that the 
dynamics of the wars of the 1990s were in many ways another response to earlier conflicts that are often cited as "proof" of ancient ethnic hatreds and the overwhelming power of ethnic identity(Gagnon Jr. 1995: 179-197). However, Yugoslavia was not an exception in comparison to other transitional postcommunist countries. In 1990, Polish dissident Adam Michnik wrote that "nationalism is the last stage of communism: a system of thought that gives simple but wrong answers to complex questions" (Der Spiegel 2013). As Sabrina Petra Ramet picturesquely noted, "the paranoia of nationalism appeared everywhere in south-east Europe after 1987"; it manifested itself "in Dedijer's wild-eyed howling about the Vatican-Comintern conspiracy against the Serbs; in Csurka's frantic warnings about the capitalist-Jewish-Masonic conspiracy against the Hungarians; in the occasional sermons of Zhirinovsky on the need of all Slavs to unite in self-defence; in the frequent articles on Germany as the 'Fourth Reich' published in Milošević's press in the late 1980s and early 1990s" (Ramet 2004: 58).

On the other hand, there was a significant difference between Yugoslavia and other transitional countries. Yugoslavia had been arguably an open although communist - country and, as some observers thought, the most successful experiment in building a multinational society in Europe since the Second World War (Denitch 1994: 1). The unravelling of the Yugoslav federal state union dictated a redefinition of the status of the republics as its constituent units; in this process the question of redefining national identities came to the forefront. Even before the formal collapse of Yugoslavia, endless discussions on the self-determination and secession rights of the nation were held, while issues concerning the historical and cultural legacy of each individual nation reemerged, as did, consequently, the question of national identities as the basis for statehood.

\section{Establishment of the Croatian nation-state and identity in flux}

One of the fundamental problems of achieving state independence with regard to identity issues was the definition of political nation; ethno-confessional identity became the prevailing identity pattern and demarcation line among nations. Questions of national survival and defence of the "living space" imposed the problem of defining the borders of the new state. The territory, and not the people, became the priority of all nationalist and greater state programs. The population was often treated "as a demographic war-base or as a replacement herd" (Topalović 2000: 60). In the imagination of some of the leading Croatian 
and Serbian politicians, the borders of the newly established nation-states were supposed to include as much of the parent nation as possible; these tendencies influenced the state-building concepts and inevitably reflected in the perception of identity (e.g. the Yugoslav nationality disappeared). Moreover, a nationally homogeneous space began to be treated as one of the main factors of regional stability.

The conflict between two revolutionary concepts of Croatian statehood (the Ustasha and the communists) during the Second World War was crucial to the development of the Croatian state idea in the post-war era (Bing 2013: 129154). Despite the all-Croatian reconciliation proclaimed by Franjo Tuđman, who was elected Croatia's president in 1991, two divergent notions of Croatian statehood came to the fore: the nationalist Independent State of Croatia (NDH) and "communist Partisan Croatia" as a part of a new Yugoslav state (Sirotković 2002: 140).

Within these ideological differences in interpretations of identity, the fundamental divergence pertained to two different concepts of the political nation and state territory, which was ultimately reflected in the policy towards minority issues (Bing 2015). In both options, the nation was one of the central political issues. Socialist internationalism and transnational Yugoslav identity never seriously challenged national particularism and interests; moreover, the affirmation of the Yugoslav republics as a nation-state in the Yugoslav Constitution of 1974 (a federation with elements of confederation) was confirmed by Josip Broz Tito (Ribičič, Tomac 1989). On the other hand, Tuđman's reconciliation policy facilitated the reaffirmation of different versions of political nation concepts. They reaffirmed the "preserved" historical identity (especially from the period of the NDH); e.g., members of the Muslim and, in the rarer cases, of the Orthodox faith were actually deemed political Croats (in the sense of the political nation). Identity issues directly reflected the interpretation of the territorial reach of each nation-state. In contrast to the 'communist' versions of the territorial organization, i.e., the Socialist Republic of Croatia, which was based on the so-called AVNOJ borders established after World War II, most Croatian political émigrés referred to Croatian ethnic and historical territories (Independent State of Croatia 1990). The uncritical linkage of "all Croatian lands", which primarily pertained to parts of Bosnia inhabited by Croats, can be seen as a Croatian counterpart to the Greater Serbia project ("all Serbs in one state") (Bassiouni 1994). 
The exclusive interpretation of national self-determination (proclaimed by all Yugoslav nations) and the overlapping of "ethnic and historical" territory led to contentious disputes not only among the Yugoslav peoples, but also within individual national bodies. The nationalist argument was accepted with some reserve in the international community, as noted by Sabrina P. Ramet, one "can't say that ethnarchy and the concept of the nation-state are atavisms"; the very idea of state-building (in the case of Serbia, the "Piedmontization" of Yugoslavia, in the case of Croatia, the historical statehood right tradition) was seen in the West as "anti-democratic and anti-liberal", and the main obstacle to the formation of a liberal-democratic state (Ramet 2001: 80).

British historian and sociologist John B. Allcock noted that the idea of building a Croatian state based on the Croatian tradition of its historical statehood right collided with the fragmentation and historical discontinuity of "Croatian historical and ethnic territories"; he therefore observed that the "Croats have a particularly problematic and confusing picture of the relationship between space and the nation" (Allcock 2000: 341). In Allcock's analysis, the Croatian statehood tradition ("one of the strongest elements of Croatian nationalism") is considered the "legal continuity of statehood appearing in discontinuity through a series of political entities"; Allcock further noted that it is "expressed with great clarity (although in historically tendentious manner)" in the preamble of the 1991 Croatian Constitution and that such a formulation is used "to avoid direct contact with potentially uncomfortable questions" about a specific area built on different definitions of Croatia (Allcock 2000: 343). Although one can debate Allcock's observations, they are relevant to the problems of legitimization of the nation-state in the process of its constitution, which were directly reflected on issues of identity change.

\section{Nationalism and identity change}

As Ivo Banac noted, there is "an underlying pattern that continues across the conflicts in the former Yugoslavia, from the attack on Slovenia all the way through to the campaign in Kosovo and even its spill-over into Macedonia in 2001, namely that ethnic cleansing and the construction of nationally homogenous states were not the consequence of but rather the aim of war". Although "this proposition might not have been obvious to all parties in the encounter at the beginning of the war", and it certainly was not the same in different parts of Yugoslavia (as well as in various segments of Yugoslav society), "it became their common stock in the course of the conflict". The concept of 
national homogeneity became the predominant political pattern: "The leaders of the Serb, Croat, Bosniac, Kosovar Albanian and other national communities, with variations, evidently believed that national homogeneity, that is, statehood without minorities, constituted political stability and offered the only genuine chance for peace" (Banac 2006: 30). This processes enforced national mobilization which in some extreme cases led to an open genocide, euphemistically called "ethnic cleansing" (Gutman 1993).

As observed by Michael Ignatieff, the first politician to begin exploiting nationalist rhetoric anywhere in Eastern Europe was Slobodan Milošević (Ignatieff 1994). His so-called "anti-bureaucratic revolution" and "homogenization of the Serbian nation" sparked the rebellion of the Croatian Serbs, who became the fifth column of Greater Serbia aspirations. At the beginning of the 1990s, aggressive Serbian nationalism greatly influenced the direction of democratic change in the remaining Yugoslav republics, validating nationalism and ethnic homogenization as the dominant social trend (Bing 2008: 215). The ultimate consequence of Milošević's demagogic attempt to reconcile "the communist notion of unity with national homogenisation" ended - to paraphrase Philip Gourevitch - with the occurrence of "genocide as an exercise in building community" (Svendsen 2011: 121).

Despite significant differences, the Croatian national homogenization pattern was not deprived of controversies as well. As noted by Michael Libal, a historian, political scientist and the head of the South-eastern Europe Department in the German Ministry of Foreign Affairs: "There was an apparent lack of sensibility by Croatian nationalists toward the Serbian memory of the Ustasha genocide and the legitimate concerns of the Serbs for their rights as distinct ethnic communities who lived in Croatia" (Libal 2004: 160). Moreover, Libal warned that "there was no doubt that Tuđman and his followers needlessly antagonized the Serbs who lived in Croatia, and that with each repetition of pressure and increase in violence against Croatia, the position of Serbs in there as held by Croats further deteriorated". However, he also claimed that those tendencies "could not be taken as evidence of the determination of the Croats to systematically violate the human and civil rights of Serbs living in Croatia", or as "an evidence of a looming mass murder or genocide of the Ustasha type" (Libal 2004: 149).

On the other hand, the distribution of the Serbian population in Croatia clearly indicated that "in the Greater Serbia program, geopolitical facilities have a higher priority than the life of Croatian and Bosnian Serb". In 1991, the Serbs in 
Croatia accounted $12.1 \%$ of the population (581,663 inhabitants), while only $3.1 \%$ of these Serbs (who together with the local Croats - themselves $1.4 \%$ of the total - accounted for a total of $4.5 \%$ of Croatia's population) lived in the territory of the 11 municipalities in which they were an absolute majority (Topalović 2000: 59). Even in the case of establishing the borders of Greater Serbian, approximately $30 \%$ of the Croatian Serbs would have still remained in Croatia. Therefore, the geopolitical projections of the Serbian regime "would leave about 175,000 Croatian Serbs in the 'Ustasha state' or enforce so-called humane resettlement" (Topalović 2000: 60,61).

Furthermore, the revival of Croatian nationalism led to peculiar and perplexing consequences. An assertion made by radical nationalists, mainly on the fringes of the Croatian political spectrum but also in the Croatian parliament, was that there were no Serbs in Croatia. The Serbs were actually Croats of the Orthodox faith. This claim was based on $19^{\text {th }}$ century nation-building idea of Croatian politician and ideologue Ante Starčević, who claimed that all Slavs in South-east Europe with the exception of the Bulgarians were Croats (Diklić 2007: 22 , 23). But this view had an inconvenient consequence. The official interpretation of the character of the war raging in Croatia - unanimously supported by the national radicals -was that it was a case of Greater Serbian aggression; in other words, it was an attack and not a civil war. But according to the logic of radical nationalists, the war in Croatia was being fought between Catholic and Orthodox Croats. Therefore it was not just a civil, but moreover a fratricidal war as well.

The members of the Croatian Peasant Party, as well as the Croatian Ustasha political émigré community of Muslim faith, who preserved the notion of the statehood tradition in the 1990s, became victims of ethno-confessional "purification" in Bosnia-Herzegovina (which was a part of the NDH during World War II) (Čolan 1990). Bosniak Muslims in Bosnia-Herzegovina had a different vision of national identity and statehood, distancing themselves from the Serbs and the Croats alike. Due to national homogenization, which required the redefinition of Croat national unity in terms of confessional uniformity, Bosniak Muslims became an obstacle to an ethnically pure and thus stable state. Finally, the ethno religious division of Croats and Bosniak Muslims led to some of the fiercest bloodshed in the Yugoslav wars (e.g. in city of Mostar). One of the consequences of this conflict was the practical disappearance of the Croats of the Muslim faith as an identity and political factor. According to the last census in 2016, in Bosnia-Herzegovina there are no Croats of Muslim faith (Croats are 
Catholics only), while in Croatia Bosniak Muslims are either national minority or declare themselves as Croats (Dnevnik.hr 2013).

This brief sketch on ideological and identity confusion was a lesser part of the problem. The refusal of the rebel Serbs to accept any Croatian state deepened Croatian-Serbian antagonism and influenced the status of the remainder of the Serbian minority in the unoccupied areas. One of the most compromising aspects of Croatian politics at the time was the terror against Serbs living in the unoccupied areas of the newly-established Croatian state in latter half of 1991 and throughout 1992 (Magaš 2006: 120). Besides criticism of Croatian policies toward Bosnia-Herzegovina, the violation of Serb minority rights led to a radical shift in which many advocates of Croatian independence, such as German human rights activist Tilman Zulch or Viktor Meier, a reporter for the Frankfurter Allgemeine Zeitung and a foremost expert on Yugoslavia, criticized Croatian politics in no uncertain terms (Buden 1996/7: 36-38). Despite mounting criticism, some of the leading politicians in the region did not hesitate to attempt enforcing the old Balkan recipe for confrontation of nations: the idea of "humane" population transfers.

\section{"Humane resettlement"}

One of the most bizarre and controversial consequences of the extreme politicization of national identity was the attempt by Croatian and Serbian leaders to implement the "humane resettlement": exchanges of "undesirable" minorities as a solution to national conflicts. The idea of the "humane resettlement" of populations, no strangers in Balkan history, fell on fertile ground after the spread of the conflict to Bosnia-Herzegovina in 1992. On 30 September 1992, Croatian President Franjo Tuđman and the president of the Federal Republic of Yugoslavia, Dobrica Ćosić, signed a solemn declaration which actually fostered the idea of population exchanges (Ramacharan 1997: 457). According to Geert-Hinrich Ahrens, who served as Ambassador-at-Large to the International Conference on the Former Yugoslavia (1992-1996), the declaration "was full of good and mostly not very realistic intentions, and contained the following sentence: 'An agreement was reached with regard to more resolute action concerning the return of displaced persons to their homes, and allowing for a voluntary and humane resettlement of those persons wishing to do so between the two States'” (emphasis added) (Ramacharan 1997: 457; Ahrens 2007: 261).

The document was also signed by the co-chairs of International Conference on Former Yugoslavia (ICFY), David Owen and Cyrus Vance. According 
to Ahrens, the agreement on "humane resettlement" was seen as a problematic aspect of the negotiations: "it should have never been underwritten by two impeccable Western democrats" (Ahrens 2007: 261). Ahrens expressed the opinion that Owen and Vance "were obviously unaware of the situation on the ground, the notorious advertisements of property exchange, Vojislav Šešelj's declarations on expulsion of non-Serb populations, and the desire of the Belgrade and Zagreb leaderships for ethically 'clean' states" (Ahrens 2007: 261). Bela Tonković, a representative of the Croats in Vojvodina, warned of a direct negative effect of this declaration on the Vojvodina Croats in Srijem, i.e., they were pressured to leave their homes and move to Croatia (Jakić 1998: 76).Ahrens' assessments on the conduct of Western diplomats (in relation to their Balkan counterparts) may also be viewed in the context of accountability for the consequences of such agreements. In any case, "humane resettlement" became imposed as one of the arguments (proofs) of "negotiated" ethnic cleansing by the warring sides, or a political consensus between the Serbs and Croats on evidence of the impossibility of restoring the multiethnic concept of society.

The key figure whose ideological and political views dictated the configuration of all aspects of the new Croatian politics was Franjo Tuđman, a former general in Tito's Yugoslav Army, a historian, communist dissident and the first elected president of the independent Croatian state. Despite his genuine desire to have Croatia join the democratic West (Požar 1990: 11-21), it was apparent that Tuđman actually never overcame the exclusivity of the totalitarian system within which his political convictions were formed. In his most important book, Bespuća povijesne zbiljnosti (translated into English as Horrors of War), written during the eighties and published in 1989, Tuđman wrote: "All of this successive pogrom violence against vast multitudes (sometimes numbering in the millions) of populations of different ethnicity always had as their aim some 'final' solution: the removal of the foreign - if not hostile or fifth-columnist historically isolated or contentious element from the ethnic and territorial fabric of one's own national body"; Tuđman further noted how "the constant repetition of (...) such violent, and even genocidal changes (...) always bring dual consequences. On the one hand, they inescapably deepen historical divisions. (...) On the other, it leads to ethnic homogenization among individual nations, to greater harmony among the national composition of the populations and state borders of individual countries, so this can have positive effects on future trends in the sense of reducing the reasons for new violence and causing new conflicts and international ruptures" (Tuđman 1994: 163). 
One can observe that Bespuća reflects an obsolete and rather pessimistic worldview on the nature of inter-human relations. However, some of the most influential modern analysts of present-day national problems have highlighted the dangers of extolling the belief in the irreconcilable nature of cultural differences. Ernest Gellner, for example, warned that the efforts to bring to fruition the nationalist imperative under certain circumstances (such as the case of the former Yugoslavia) must "include exchanges or expulsions of populations, more or less coerced assimilation, and sometimes even executions, in order to achieve that close relationship between state and culture which forms the essence of nationalism" (Gellner 1996: 175). Uta Grahardt, following on the observations of Zygmont Baumant, noticed that such events "always carry potentially reproducible connections between the crime with the idea of purified cultures" (Vrcan 2002: 24).

According to documentation compiled by the International Criminal Tribunal for the former Yugoslavia (ICTY),Tuđman took the declaration rather seriously; when the Croatian President and his associates discussed what to do with the Serbs in Croatia on 17 November 1994, he said that he had signed the Agreement on Voluntary Relocation with then Yugoslav President Dobrica Ćosić and Serbian President Slobodan Milosevic, and "if there is mutual diplomatic recognition between Croatia and Serbia, the Serbs who do not want to live in Croatia should simply leave" (Šoštarić 2007). An ethnically homogeneous space as a factor of stability remained as a constant in Franjo Tuđman's policy after the war as well. Something that could be heard in "official circles "even in 1996 was that the "titular nation must have 80 to 90 percent of the population" as a precondition for "development of the state and democracy" (Topalović 2000: 35). In a speech held in Vukovar on June 8, 1997, during the peaceful reintegration of eastern Croatia, Tuđman assured the Serbs from the Danube region that they would enjoy equality and well-being just like all other Croatian citizens. However, he warned that "it goes without saying that there can be no question of all one hundred and fifty or two hundred thousand (Serbs) returning, so that we once again endure internal strife and war (...) History is what it is: after World War I there was a great population exchange between Turkey and Greece. Approximately six hundred and fifty thousand Turks from Greece moved to Turkey, and about one million and three hundred thousand Greeks moved from Asia Minor to Greece, etc. So not all evil ends in evil. After such evil some good also results" (Tuđman 1998: 295). 
How did the Croatian public respond to this ideas of population exchanges? At the time when the war was escalating, the idea of population exchanges between the warring parties remained relatively obscure in public life. It is also interesting that the text of declaration was presented to the Croatian public in somewhat amended form: "An agreement was reached on decisive action to return displaced persons to their homes and to allow voluntary and humane renewed settlement of persons who so wish between the two states" (the expression renewed settlement is used instead of resettlement) (Slobodna Dalmacija 1992). Half a year after the Tuđman-Ćosić declaration, the Croatian weekly news magazine Danas published several articles dealing with "humanitarian and voluntary resettlement"; the focal point was the allegation that "today many people see such a solution as the only one that would ensure the long term peace in the region" ("co-existence would be possible only with barbed wire in between, in which both Serbs and Croats will be inmates)" (Popović 1993: 10). However, one of the articles presented a survey which showed that "most of the citizens of Split and Zagreb do not believe that the war would be stopped by the so-called humane transfer of populations" (Šola 1993: 12).

The statements by officials and politicians reflected ambivalent attitudes. Despite some misgivings, the chairman of the Croatian Parliamentary Committee on Human and Minority Rights, Ljubomir Antić, expressed the opinion that it is "legitimate to ask whether it makes sense to insist on certain principles", if "living together in certain areas is impossible, if forcing coexistence creates additional tension which then leads to conflicts and crimes". Antić concluded that "here is no sense in being hypocritical" and if "no one is happy, not even most minorities, then it is also legitimate to consider the implementation of humane displacement" (Popović 1993: 10).The deputy chairman of the Croatian SocioLiberal Party (of which Antić was also a member), Božo Kovačević, was more reserved. "I believe that Croatia must not agree to toy with the idea of relocation of populations because it actually signifies an indirect recognition of the results of Serbian ethnic cleansing". Kovačević also warned that the eventual wishes of "minority ethnic groups who want to leave the state in which they live says more about their sense of insecurity" (Popović 1993: 10). One of the fiercest critics of Tuđman's policies during the 1990s (and, ironically, his present-day apologist) Zdravko Tomac, observed: “Dr. Franjo Tuđman signed, together with Dobrica Ćosić, the current president of the Federal Republic of Yugoslavia, an agreement on so-called humane resettlement, whereby politically Croatia officially endorsed 
the Greater Serbian idea of ethnically clean states as an alleged guarantor of peace and stability" (Tomac 1999: 109; Hartman 2002: 216).

A few years later historian and prominent liberal and human rights activist Ivo Banac, resolutely rejected any idea of population exchanges: "There is no humane relocation. To believe that the absence of a minority population is prerequisite for a country's stability is a major misconception" (Roknić 2007). In an overall assessment of Tuđman's democratic deficit, sociologist Srđan Vrcan observed that the first Croatian president "did not seek reasons for the impossibility of the Croats and Serbs living together in a common state and for the necessity of secession in the wrong-headed, discriminatory or repressive and undemocratic systemic institutional arrangements - rather he sought them in deeper and more irrevocable differences in culture between the Croats and Serbs which make any form of coexistence between them impossible and unsustainable" (Vrcan 2002).

The attempt to enforce exchanges of undesirable populations between Croatia and Serbia did not go unnoticed by the ICTY when compiling the indictment against Croatian generals Ante Gotovina, Ivan Čermak and Mladen Markać (Šoštarić 2007). The prosecution managed to acquire a series of transcripts according to which the plan to drive Serbs out of Croatia was initiated as far back as 1992 in line with Tuđman's idea of the "humane" resettlement of the population, which was confirmed by a number of his other statements, and the statements of his closest associates in the period from 1992 to 1996 . The prosecution claimed that "the expulsion of the Serbs from the Krajina area was in fact the long-term interest of President Tuđman linked to the idea of a need for ethnically homogenous nations on a given territory". Tuđman "saw the ethnic splintering in the territory of Yugoslavia as a historical problem that could be addressed (...) by the relocation of populations from one area to another" (Šoštarić 2007).

It is an open question whether Tudjman - had he lived longer - would have been tried in The Hague. Nevertheless, controversies are still present in post-Yugoslav societies due to issues such as "humane resettlement". Serbian historian Momčilo Mitrović noted in 2007 that "there is no doubt that the independence of the countries in the former Yugoslavia was accompanied by premeditated, planned and organized ethnic cleansing of the territory of the projected or actual state communities. It is certain that all of these future states wanted clean or as 'cleaner' ethnic territories for their future nation-states as a strategic objective. (...) It is quite clear that there were formulated methods 
underlying ethnic cleansing in all three warring parties" (Mitrović 2003: 89, 94). Croatian social science still lacks more critical approach to sensitive issues of recent history such as the role of state officials in the creation of ethnically homogenous areas. It was therefore possible for an organization of Croatian war veterans submitting a request to the public prosecutor to raise an indictment against Dobrica Ćosić for the crime of "humane resettlement" while simultaneously deifying the first Croatian president (Index.hr 2007).In this way, a controversy from the past is conveyed to the present in a new form.

\section{Conclusion}

Under the conditions of a war waged on a national basis, the reference to differences in identity and culture produced a situation in which the legitimacy of barbarism came to the fore in the form of "absolute and total exclusion" of that part of the population now redefined as the "complete others". It produced a new type of xenophobia, a new call for the substantiality of cultural identity and the 'proper' distinction and affirmation of every ethnic and cultural identity. Modern historiography has yet to examine and contextualize the particular forms of "ethnic cleansing" - the creation of ethnically homogenous areas - and establish the correlation to and historical significance of the "nationalism" that developed among the peoples of the former Yugoslavia.

In that sense, the role of the first Croatian president, Franjo Tuđman, is still an open question. A fixation with the nation and national relations, heightened by the historical flux of "eternal war", wherein the "toxic and constant rivalry" between the Serbs and Croats figured prominently, served as an inexhaustible source of inspiration to the historian and statesman Tuđman. In its essence, Tuđman's historicism was the Marxist deterministic folly on the unavoidable necessity of individual historical flows (e.g., the conviction that the only solution to clashing class relations is revolution) which was reflected in his stance on the resolution of "antagonistic" relations between nations.

Although Tuđman was neither a racist nor a fascist, his nationalism was outmoded. He strongly believed that multiethnic societies were not possible under post-Yugoslav conditions. The case of acceptance of population displacement as real-political/historicist matrix, resting on "the experience of centuries of events", contradicted commitments to democracy and human rights. Moreover, the case of the violent collapse of the Yugoslav state showed that that "ethnic cleansing" could easily become a state-building method (as was 
the case when the document on "humane resettlement" was signed while the war raged).

In that complex historical context, many dilemmas that arose in the Yugoslav drama (only a small part thereof was covered herein) can be associated with some principle issues: how to apply the right of national self-determination in times of turmoil or war? Can the right to a (nation) state deny minorities their right to a homeland? What is the relationship of contemporary Realpolitik and geopolitics? Can national interests and statehood aspirations become a priority in relation to certain fundamental questions of ethics and the legitimacy of political actions? How can we distinguish different degrees of evil within a specific historical context?

\section{Bibliography}

\section{AHRENS 2007}

Geert-Hinrich Ahrens, Diplomacy on the Edge-Containment of the Ethnic Conflict and the Minorities Working Group of the Conferences on Yugoslavia, Washington DC, Baltimore 2007.

\section{ALLCOCK 2000}

John Allcock, Explaining Yugoslavia, London 2000.

\section{BANAC 2006}

Ivo Banac, "The politics of national homogeneity", War and Change in the Balkans, Nationalism, Conflict and Cooperation, (ed. B. K. Blitz), New York 2006.

\section{BASSIOUNI 1994}

Cherif Bassiouni, (28 December 1994). "Final Report of the Commission of Experts Established Pursuant to Security Council Resolution 780, United Nations

BING 2008

Albert Bing, "Hrvatska i ljudskaprava 1990.-1992.- okvir za istraživanje (etnocentrizam, autoritarni populizam, ljudska prava i demokracija)", Časopis za suvremenu povijest, 1, Zagreb 2008.

BING 2013

Albert Bing, "Samoodređenje naroda i koncepcije hrvatske državnosti u kontekstu Drugog svjetskog rata - refleksije povijesnog kontinuiteta," Radovi, 45, Zagreb 2013, 129 - 154. 
BING 2015

Albert Bing, "Nacionalne manjine i državno osamostaljenje Hrvatske," Nacionalne manjine u Hrvatskoj i Hrvati kao manjina-Europski izazovi, Zagreb, 2015.

BUDEN 1996

Boris Buden, Barikade 2, Zagreb 1996/7.

ČOLAN 1990

Zbornik - Časopis Hrvatske seljačke stranke za kulturna, društvena i politička pitanja s kalendarom 1990. (eds. M. Čolan, F. Salihović, A. Lepić and M. Šuk), London, 1990.

ČOVIĆ 1991

Bože Čović (ed.), Izvori velikosrpske agresije - rasprave, dokumenti, kartografski prikazi, Zagreb 1991.

DENITCH 1994

Bogdan Denitch, Ethnic Nationalism, The Tragic Death of Yugoslavia, Minneapolis, London 1994.

DER SPIEGEL 2013

Interview: "Polish Dissident Adam Michnik: 'We Are Bastards of Communism,'” Der Spiegel, 31 July, 2013.

DIKLIĆ 2007

Marjan Diklić, "Dr. Ante Starčević: U povodu 110 obljetnice smrti (1823.1896.)," Pravaška misao i politika (eds. J. Turkalj, Z. Matijević and S. Matković), Zagreb 2007, 22.-23.

DIMITRIJEVIĆ 2012

Vojin Dimitrijević, "Constitutional Ethno-Nationalism after Feefteen Years," After Yugoslavia: Identities and Politics within the Successor States (eds. Robert Hudson and Glenn Bowman), New York 2012.

GAGNON Jr. 1995

V.P. Gagnon Jr., "Historical Roots of the Yugoslav Confict," International Organizations and Ethnic Conflict (eds. M. Esman and S. Telhami), Ithaca 1995.

GELLNER 1996

Ernest Gellner, Conditions of Liberty. Civil Society and its Rivals, London 1996. 
194

GUTMAN 1993

Roy Gutman, A witness to genocide: The 1993 Pulitzer Prize-Winning

Dispatches on the "Ethnic Cleansing," New York 1993.

HARTMANN 2002

Florence Hartmann, Milošević - Dijagonala luđaka, Zagreb/Rijeka 2002.

DNEVNIK.HR 2016

http://dnevnik.hr/vijesti/svijet/objava-rezultata-popisa-stanovnistva-ubih-iz-2013-koliko-ima-bosnjaka-srba-i-hrvata---441880.html

INDEX.HR 2007

http://www.index.hr/vijesti/clanak/ubiudr-trazi-optuznicu-protiv-

dobrice-cosica/350501.aspx

\section{IGNATIEFF 1994}

Michael Ignatieff, Blood and Belonging, London 1994.

INDEPENDENT STATE OF CROATIA

Independent State of Croatia, Year XXIX, No 10 (394) Oct. 1990.

JAKIĆ 1998

Tomislav Jakić (ed.), Radijski razgovor Milorad PUPOVAC i Bela TONKOVIĆ, Srbi u Hrvatskoj i Hrvati u Srbiji, Mostovi dijaloga: razgovori ratu usprkos, Prag, Banja Luka 1998.

LIBAL 2004

Michael Libal, Njemačka politika i jugoslavenska kriza 1991.-1992.,

Zagreb 2004.

MAGAŠ 2006

Branka Magaš, "The War in Croatia," War and Change in the Balkans,

Nationalism, Conflict and Cooperation (ed. B. K. Blitz), New York 2006.

MINC 2008

Alain Minc, Novi srednji vijek, Zagreb 2008.

MITROVIĆ 2003

Momčilo Mitrović, "Etničko čišćenje Srba iz grada Zagreba 1992 - 1994."

Tokovi istorije 3-4, Beograd, 2003.

POPOVIĆ 1993

Edvard Popović, “Preseljenje ili istrebljenje,” Danas, 21 May, 1993, 10. 


\section{POŽAR 1990}

Tuđman's speech to the Croatian Parliament: "Sabor na braniku hrvatske državne samobitnosti," Hrvatske pravice, (ed. P. Požar), Split-Zagreb 1990. (Based on Vjesnik, May 31, 1991)

PRICA 2012

Ines Prica, "Singing the Politics of Croatian Transition," After Yugoslavia: Identities and Politics Within the Successor States (eds. R. Hudson and G. Bowman), New York 2012.

\section{RAMACHARAN 1997}

B.G. Ramacharan (ed.), The International Conference on the Former Yugoslavia: Official Papers, 2, The Hague 1997.

\section{RAMET 2000}

Sabrina P.Ramet, Čija demokracija? Nacionalizam, religija i doktrina kolektivnih prava u srednjoj i jugoistočnoj Europi nakon 1989. godine, Zagreb 2000.

\section{RAMET 2004}

Sabrina P.Ramet, Postkomunistička Europa i tradicija prirodnoga prava, Zagreb 2004.

RIBIČIČ, TOMAC 1989

Ciril Ribičič, Zdravko Tomac, Federalizam po mjeri budućnosti, Zagreb 1989.

ROKNIĆ 2007

Marko Roknić, "Intervju s Ivom Bancem, Ne mogu zamisliti Hrvatsku bez Srba," Identitet, srpanj - jul 2007.

\section{SIROTKOVIĆ 20002}

Hodimir Sirotković, ZAVNOH. Rasprave i dokumenti, Zagreb 2002.

\section{SLOBODNA DALMACIJA 1992}

Slobodna Dalmacija, 2 October 1992.

\section{SVENDSEN 2011}

Lars Fr. H. Svendsen, Filozofija zla, Zagreb 2011.

ŠOLA 1993

Franko Šola, “Seobe bez zagovornika," Danas, 21 May 1993, 12. 
196

ŠOŠTARIĆ 2007

Eduard Šoštarić, "17 transkripata i tisuće dokaza protiv generala,"

Nacional, 3 March 2007.

TOMAC 1999

Zdravko Tomac, Zločin bez kazne, VI. Velikohrvatski nacionalizam, Zagreb 1999.

TOPALOVIĆ 2000

Duško Topalović, Balkanska Europa, Zagreb 2000, 35. (Novi list, 10 February 1996).

TUĐMAN 1994

Franjo Tuđman, Bespuća povijesne zbiljnosti, Zagreb 1994.

TUĐMAN 1998

Franjo Tuđman, Zna se, HDZ u borbi za učvršćenje hrvatske državne suverenosti, Zagreb 1998.

VRCAN 2002

Srđan Vrcan, "Etničko kao krinka za nacionalizam," Etničnost i stabilnost Europe u 21. stoljeću (ed. S. Mežnarić), Zagreb 2002. 